\title{
Pengembangan Bahan Ajar Sejarah Daerah Bima Berbantu Quick Response Codes Kelas X SMA Negeri 1 Woha
}

\author{
Nasruddin \\ STKIP AL-Amin Dompu \\ E-mail: bima.monta@gmail.com
}

\begin{abstract}
The results of early observation found local content teaching materials history of Bima region in state Senior high school (SMAN) 1 Woha, during the time only printed materials that is kind of photocopy that only displays visually and impressed linear, teaching materials that have not combine audio visual that can be accessed directly by the learner throughout Android and smartphones, as the result students have difficulty in understanding the learning materials. In development of this instructional material has a goal to produce local content teaching history of Bima region is assisted by QR code. The development using dick and Carey's model which are modified by eliminating the formative evaluation. The development of local content materials history of Bima region is asserted very proper to be used as a learning material with percentage of material lessons reach $87 \% .86 \%$ of teacher guide, and $86 \%$ of students guide.
\end{abstract}

Keyword: Development, Material Lessons, Qr Codes, Dick And Carey’s Model

Abstrak: Hasil observasi awal ditemukan bahan ajar muatan lokal sejarah daerah bima di SMA N 1 Woha selama ini hanya sebatas bahan ajar cetak berupa fotocopy yang hanya menampilkan secara visual dan terkesan linear, bahan ajar yang ada belum menggabungkan audio visual yang dapat diakses langsung oleh pebelajar melalui android atau smartphone, sehingga siswa mengalami kesulitan dalam memahami materi pelajaran. Dalam pengembangan bahan ajar ini mempunyai tujuan untuk menghasilkan bahan ajar muatan lokal sejarah daerah bima berbantu $Q R$ Codes. Model pengembangan menggunakan Dick \& Carey yang dimodifikasi dengan menghilangkan evaluasi formatif. Pengembangan bahan ajar muatan lokal sejarah daerah bima dinyatakan sangat layak untuk digunakan sebagai bahan pembelajaran dengan persentase bahan ajar mencapai $87 \%$, panduan guru $86 \%$, panduan siswa $86 \%$.

\section{Kata Kunci: Pengembangan, Bahan Ajar, Qr Codes, Model Dick \& Carey}

\section{PENDAHULUAN}

Bahan ajar adalah bagian integral dalam proses pebelajaran. Untuk mencapai proses pembelajaran yang sesuai dengan tujuan pendidikan nasional (TUPENAS) adalah ketersediaan sumber belajar yang sesuai dengan standar kurikulum 2013. Faktor pendukung keberhasilan Kurikulum 2013 adalah ketersediaan buku sebagai bahan ajar dan sumber belajar yang mengintegrasikan teknologi di dalam proses pembelajaran. Menurut (Suhartono 2007), ada empat hal yang menjadi landasan dalam pengembangan bahan ajar, yakni: (1) untuk pembentukan kompetensi personal dan sosial, (2) kewajiban dan kewenangan bagi pembelajar, (3) perkembangan ilmu pengetahuan, teknologi dan seni yang harus selalu diikuti dan, (4) adanya pengembangan kurikulum yang menuntut pula pengembangan bahan ajar.

Peran teknologi pembelajaran sangat urgen sebagaimana definisi dari AECT 1994 bahwa teknologi pembelajaran (instructional technology) adalah teori dan praktek tentang rancangan, pengembangan, penggunaan pengelolaan dan pengevaluasian dari suatu proses dan sumber-sumber untuk belajar. Bentuk peran teknologi pembelajaran yang termasuk penyediaan sumber belajar ialah dikenal dengan istilah POBATL (pesan, orang, bahan, alat, teknik, latar) yang dipakai baik secara mandiri atau digabungkan untuk memudahkan kegiatan belajar, (Alan \& Molenda, 2008). 
Salah satu capaian yang ingin diraih dalam K13 adalah lahirnya masyarakat pebelajar yang cakap secara sosial-akademik yang merupakan manifestasi dari proses belajar yang terus menerus. Materi pelajaran untuk masyarakat pebelajar mencakup pula nilai-nilai yang berkaitan dengan kearifan lokal masyarakat. Mata pelajaran muatan lokal sejarah daerah bima merupakan salah satu alternatif yang dapat ditempuh melalui institusi pendidikan, adalah dengan cara memperkenalkan keanekaragaman dan kekayaan budaya nasional sejak dini melalui budaya yang ada di daerahnya masingmasing. Disamping itu, mata pelajajaran muatan lokal sejarah daerah bima dapat menjadi jembatan untuk memperkenalkan kearifan-kearifan lokal yang terkadung adatistiadat dan budaya daerahnya. Sehingga timbulnya rasa kebanggaan akan pendukung kebudayaan nasional, dapat mendorong dan memotivasi seseorang untuk melestarikan budaya yang ada di sekelilingnya.

Pengelolaan kurikulum 2013 yang dilakukan oleh pemerintah dalam penyediaan sumber belajar dalam hal ini bahan ajar yang belum sesuai dengan karakteristik pebelajar dan faktor psikologisnya, membuat kebutuhan bahan ajar yang sesuai dengan karakteristik dan lingkungan anak tersebut menjadi hal sangat penting, sehingga diperlukan pengembangan bahan ajar untuk melengkapi bahan ajar yang telah disediakan pemerintah.

Berdasarkan hasil observasi awal ditemukan bahan ajar muatan lokal sejarah daerah bima di SMA N 1 Woha selama ini hanya sebatas bahan ajar cetak berupa fotocopy yang hanya menampilkan secara visual dan terkesan linear, bahan ajar yang ada belum menggabungkan audio visual yang dapat diakses langsung oleh pebelajar melalui android atau smartphone, sehingga siswa mengalami kesulitan dalam memahami materi pelajaran. Dengan demikan diperlukan upaya untuk mempermudah pemahaman pebelajar dengan memberikan visualisasi siswa melalui teknologi smartphone yang melibatkan teknologi digital melalui $Q R$ Codes. Berdasarkan permasalahan di atas peneliti ingin mengembangkan bahan ajar untuk siswa
SMA N 1 Woha kelas $\mathrm{X}$ semester 1 yang disusun sesuai dengan karakteristik pebelajar dan sebagai jembatan yang dapat digunakan pebelajar dalam mengakses materi secara online dengan menggabungkan fitur $Q R$ Codes.

$Q R$ Codes adalah jenis barcode yang berbentuk dua dimensi yang dikembangkan oleh Denso Wave, sebuah divisi Denso Corporation, sebuah perusahaan di Jepang, yang dipublikasikan pada tahun 1994. $Q R$ Codes merupakan singkatan dari Quick Response (respon/tanggapan cepat), sehingga fungsi atau tujuan utama dari teknologi ini adalah penyampaian informasi dengan cepat dan mendapat tanggapan atau respons yang cepat pula. Penggunaan di dalam bahan ajar sangat di butuhkan guna memudahkan siswa dalam mengakses materi pelajaran yang bersifat audio dan visual. $Q R$ Codes merupakan wujud barcode dua dimensi yang memiliki kemampuan menyimpan informasi berupa teks atau string (Bahtiar \& Mazharuddin, 2012). Berdasarkan permasalahan diatas peneliti ingin mengembangkan bahan ajar dengan menggunakan model Dick \& Carey dan menggabungkan teknologi berbantu $Q R$ Codes sebagai pemecahan masalah tersebut.

\section{METODE PENELITIAN}

Model pengembangan bahan ajar mata pelajaran muatan lokal sejarah daerah bima menggunakan model Dick \& Carey (2009) yang dimodifikasi. Langkah-langkah pengembangannya sebagai berikut: mengidentifikasi tujuan pembelajaran; (2) melakukan analisis pembelajaran; menganalisis siswa dan konteks; merumuskan tujuan performansi; mengembangkan alat atau instrumen penilaian; (6) mengembangkan strategi pembelajaran; (7) mengembangkan dan memilih bahan ajar; (8) merancang dan melaksanakan evaluasi formatif; dan (9) melakukan revisi terhadap draf program pembelajaran.

Bahan ajar atau materi pembelajaran secara garis besar terdiri dari pengetahuan, keterampilan dan sikap yang harus dipelajari pebelajar dalam rangka mencapai standar 
kompetensi yang telah ditentukan (Depdiknas, 2006). Pendapat lain mengungkapkan bahwa jika dirancang dan dikembangkan berdasarkan prinsip-prinsip instruksional yang baik bahan ajar akan membantu mahasiswa dalam proses belajarnya, membantu dosen untuk mengurangi waktu penyajian materi dan memperbanyak waktu bimbibingan dosen bagi mahasiswa, membantu perguruan tinggi dalam menyelesaikan kurikulum dan mencapai tujuan instruksional dengan waktu yang tersedia (Pannen \& purwanto, 2001). Dari kedua pengertian tersebut dapat ditarik kesimpulan bahwa bahan ajar adalah seperangkat materi yang disusun secara sistematis yang digunakan untuk menciptakan lingkungan belajar.

Adapun fungsi dari bahan ajar adalah: 1) sebagai pedoman guru yang akan mengarahkan semua aktivitas dalam proses pembelajaran, sekaligus merupakan substansi kompetensi yang seharusnya diajarkan pada pebelajar, 2) pedoman bagi pebelajar yang akan mengarahkan aktivitasnya dalam proses pembelajaran, sekaligus merupakan susbtansi kompetensi yang seharusnya dikuasainya, 3) sebagai alat evaluasi pencapaian/penugasan hasil belajar (Depdiknas, 2008). Penggunaan bahan ajar dapat membantu pebelajar mempelajari suatu kompetensi secara runtut dan sistematis sehingga mampu menguasai suatu kompetensi secara utuh. Pembelajaran juga perlu adanya suatu bahan ajar dengan berorientasi model pembelajaran yang dapat menumbuhkan minat siswa dan harus menuntun siswa dalam menyelesaikan suatu permasalahan dengan suatu hasil karya (Igfir Rijal, 2016).

Pengembangan bahan ajar ini memiliki strategi sebagaimana (Degeng, 1997) menyatakan bahwa strategi pembelajaran diartikan sebagai penataan caracara, sehingga terwujudnya suatu urutan langkah prosedural yang dapat digunakan untuk mencapai hasil pembelajaran yang diinginkan. Bahan ajar muatan lokal sejarah daerah bima menggunakan pendekatan saintifik karena efektivitas pemahaman Kurikulum 2013 lebih mengedepankan pada pengalaman personal peserta didik. (Rusman,
Dalam Ainun Mardiah 2016) menyatakan bahwa pendekatan saintifik adalah sebuah pendekatan pembelajaran yang menekankan pada aktivitas siswa melalui kegiatan mengamati, menanya, menalar, mencoba dan mengkomunikasikan pada kegiatan pembelajaran di sekolah. Bahan ajar dengan pendekatan saintifik pada kurikulum 2013 adalah (1) mengamati, (2) menanya, (3) mencoba(mengumpulkan data), mengasosiasi, (5) mengkomunikaiskan, sehingga peserta didik dapat menemukan fakta-fakta, membangun konsep-konsep dan teori-teori dengan keterampilan proses dan sikap ilmiah peserta didik sendiri. Dengan demikian, dapat meningkatkan potensi intelektual untuk meningkatkan kemampuan anak didik menyadari, memahami, dan menguasai rangkaian bentuk serta meningkatkan kemampuan pola pikir ilmiah.

Data yang diproleh dari uji coba bahan ajar ini bersifat kualitatif dan kuantatif. Data kualitatif berupa tanggapan dan saran perbaikan yang diperoleh dari ahli materi pelajaran, ahli media pembelajaran, uji coba perorangan, uji coba kelompok kecil, dan uji coba lapangan. Sedangkan data kuantitatif diperoleh dari hasil skor melalui angket yang disebar. Instrumen pengumpulan data pada pengembangan bahan ajar digital ini berupa angket. Berdasarkan dari bentuk pertanyaan pada instrumen, ada dua macam bentuk pertanyaan yaitu pertanyaan tertutup yang akan dikelompokkan ke dalam tabel yang berisi skala penilaian dan berupa pertanyaan terbuka yang berisi komentar dan saran. Angket ini menggunakan 5 (lima) tingkat penilaian menurut skala Likert Sugiyono (2011).

Teknik analisis ini digunakan untuk mengolah data yang diperoleh melalui angket dalam bentuk deskriptif persentase. Rumus yang digunakan untuk menghitung persentase dari masing-masing subjek adalah:

Keterangan:

$$
P=\frac{X}{X i} \times 100 \%
$$

\section{$\mathrm{P}$ : Persentase}

$\mathrm{X}$ : Jumlah skor jawaban seluruh responden dalam satu item 
Xi : Jumlah skor ideal dalam satu item

Selanjutnya, untuk menghitung persentase keseluruhan subyek digunakan rumus:

$$
P=\frac{\sum X}{\sum X i} \times 100 \%
$$

Keterangan :

$\mathrm{P}:$ Persentase $(\%)$

$\Sigma \mathrm{X}$ : Jumlah keseluruhan skor jawaban seluruh responden

$\Sigma \mathrm{Xi}$ : Jumlah keseluruhan skor ideal dalam

keseluruhan item (Arikunto, 2008)

Untuk dapat memberikan makna dan pengambilan keputusan, maka hasil dari data yang telah diolah dikonversikan dengan kriteria kelayakan sebagai berikut:

Tabel 3.3 Konversi Tingkat Pencapaian Penilaian Produk

\section{Tingkat}

\section{Kualifikasi}

\section{Pencapian}

\begin{tabular}{|cc}
\hline $\mathbf{8 1 \%}-\mathbf{1 0 0 \%}$ & Sangat Layak \\
$\mathbf{6 1 \%} \mathbf{- 8 0 \%}$ & Layak \\
$\mathbf{4 1 \%} \mathbf{- 6 0 \%}$ & Cukup Layak \\
$\mathbf{2 1 \%}-\mathbf{4 0 \%}$ & Kurang Layak \\
$\mathbf{0 \%} \mathbf{- 2 0 \%}$ & Tidak Layak \\
\hline
\end{tabular}

\section{HASIL DAN PEMBAHASAN}

Hasil-hasil analisis data di atas didasarkan pada hasil penilaian dari masingmasing subjek uji coba, sehingga hasil analisa tersebut berlum disimpulkan secara keseluruhan. Berikut ini adalah hasil analisa penilaian secara keseluruhan.

a. Bahan Ajar

Analisa data dari hasil angket subjek uji coba secara keseluruhan mengenai kelayakan bahan ajar akan dipaparkan dalam tabel berikut.

\section{Tabel 1. Hasil Penilaian Persentase Keseluruhan Subjek Uji Coba terhadap Bahan Ajar}

\begin{tabular}{|l|l|c|c|c|c|}
\hline No & \multicolumn{1}{|c|}{ Subjek Uji Coba } & $\begin{array}{c}\text { Skor } \\
\text { Maksmial }\end{array}$ & $\begin{array}{c}\text { Skor } \\
\text { Penilaian }\end{array}$ & $\begin{array}{c}\text { Pesersen } \\
\text { tase }\end{array}$ & Keterangan \\
\hline 1 & Ahli Isi & 65 & 75 & $87 \%$ & Sangat layak \\
\hline 2 & Ahli Desain & 66 & 80 & $83 \%$ & Sangat layak \\
\hline 3 & Ahli Media & 70 & 80 & $88 \%$ & Sangat layak \\
\hline 4 & Uji Coba Perorangan & 162 & 180 & $90 \%$ & Sangat layak \\
\hline 5 & Uji Coba Kelompok Kecil & 308 & 360 & $86 \%$ & Sangat layak \\
\hline 6 & Uji Coba Lapangan & 1464 & 1680 & $88 \%$ & Sangat layak \\
\hline \multicolumn{2}{c|}{ Jumlah } & 2135 & 2455 & $87 \%$ & Sangat layak \\
\hline
\end{tabular}

Hasil analisis tabel 1. tersebut dapat diketahui bahwa secara keseluruhan persentase bahan ajar dari keseluruhan subjek uji coba mencapai $87 \%$. Berdasarkan tabel persentase kelayakan dapat disimpulkan bahwa pengembangan bahan ajar sejarah daerah bima termasuk dalam kriteria sangat layak untuk digunakan sebagai bahan pembelajaran di SMA N 1 Woha.

\section{b. Panduan Guru}

Analisa data dari hasil angket subjek uji coba secara keseluruhan mengenai kelayakan panduan guru akan dipaparkan dalam tabel berikut.

Tabel 2. Hasil Penilaian Persentase Keseluruhan Subjek Uji Coba terhadap Panduan Guru

\begin{tabular}{|l|l|c|c|c|c|}
\hline No & \multicolumn{1}{|c|}{ Subjek Uji Coba } & $\begin{array}{c}\text { Skor } \\
\text { Maksmial }\end{array}$ & $\begin{array}{c}\text { Skor } \\
\text { Penilaian }\end{array}$ & $\begin{array}{c}\text { Pesersen } \\
\text { tase }\end{array}$ & Keterangan \\
\hline 1 & Ahli Isi & 67 & 75 & $90 \%$ & Sangat layak \\
\hline 2 & Ahli Desain & 57 & 70 & $82 \%$ & Sangat layak \\
\hline 3 & Ahli Media & 66 & 75 & $88 \%$ & Sangat layak \\
\hline \multicolumn{2}{|c|}{ Jumlah } & 189 & 220 & $86 \%$ & Sangat layak \\
\hline
\end{tabular}

Hasil analisis tabel 2. tersebut dapat diketahui bahwa secara keseluruhan persentase panduan guru dari keseluruhan subjek uji coba mencapai $86 \%$. Berdasarkan tabel persentase kelayakan dapat disimpulkan bahwa pengembangan panduan guru sejarah daerah bima termasuk dalam kriteria sangat layak untuk digunakan sebagai bahan pembelajaran di SMA N 1 Woha.

c. Panduan Siswa

Analisa data dari hasil angket subjek uji coba secara keseluruhan mengenai kelayakan panduan siswa akan dipaparkan dalam tabel berikut.

\section{Tabel 3. Hasil Penilaian \\ Persentase Keseluruhan Subjek Uji Coba terhadap Panduan}

\section{Siswa}

\begin{tabular}{|l|l|c|c|c|c|}
\hline No & \multicolumn{1}{|c|}{ Subjek Uji Coba } & $\begin{array}{c}\text { Skor } \\
\text { Maksmial }\end{array}$ & $\begin{array}{c}\text { Skor } \\
\text { Penilaian }\end{array}$ & $\begin{array}{c}\text { Pesersen } \\
\text { tase }\end{array}$ & Keterangan \\
\hline 1 & Ahli Isi & 52 & 60 & $87 \%$ & Sangat layak \\
\hline 2 & Ahli Desain & 50 & 60 & $84 \%$ & Sangat layak \\
\hline 3 & Ahli Media & 53 & 60 & $88 \%$ & Sangat layak \\
\hline 4 & Uji Coba Perorangan & 119 & 135 & $89 \%$ & Sangat layak \\
\hline 5 & Uji Coba Kelompok Kecil & 228 & 270 & $85 \%$ & Sangat layak \\
\hline 6 & Uji Coba Lapangan & 1068 & 1260 & $85 \%$ & Sangat layak \\
\hline \multicolumn{2}{|c|}{ Jumlah } & 1570 & 1845 & $86 \%$ & Sangat layak \\
\hline
\end{tabular}

Hasil analisis tabel 3. tersebut dapat diketahui bahwa secara keseluruhan persentase panduan siswa dari keseluruhan subjek uji coba mencapai $86 \%$. Berdasarkan tabel persentase kelayakan dapat disimpulkan bahwa pengembangan panduan siswa sejarah 
daerah bima termasuk dalam kriteria sangat layak untuk digunakan sebagai bahan pembelajaran di SMA N 1 Woha.

\section{KESIMPULAN}

Pengembangan dilakukan karena didasarkan beberapa hal, antara lain: 1) memperhatikan tujuan pendidikan sekolah sebagai pendidikan dasar yakni sebagai wahana untuk mengembangkan diri melalui kegiatan pendekatan belajar, serta bertindak secara nyata, 2) pembelajaran dengan pendekatan belajar, memberikan suasana keterbukaan pada sisswa karena dikembangkan melalui model Dick \& Carey dengan mengitegrasikan $Q R$ Codes.

$$
\text { Produk bahan ajar yang }
$$

dikembangkan merupakan pengembangan

dari berbagai buku yang dimodifikasi sedemikian rupa menyelesaikan karakteristik dan kebutuhan siswa, serta dilengkapi dengan panduan guru, panduan siswa. Sehingga menjadi satu paket bahan ajar. Dibandingkan dengan bahan ajar sebelumnya, paket bahan ajar ini memiliki keunikan tersendiri dikarenakan 1) dikembangkan dengan menggunakan model Dick \& Carey yang dibuktikan melalui berbagai penelitian yang telah dilakukan, dapat meningkatkan efektifitas dan efisiensi pembelajaran karena menggunakan pendekatan system yang lengkap, 2) bahan ajar disusun dan dikembangkan berdasarkan kebutuhan karakteristik siswa, 3) bahan ajar dilengkapi dengan panduan guru, panduan siswa.

Produk pengembangan terdiri dari 1)

bahan ajar untuk kepentingan belajar yang terdiri dari dua bagian yaitu, 2) panduan guru, 3) panduan siswa.

Panduan guru yang teridiri dari beberapa komponen yaitu sebagai berikut:

1. Identitas mata pelajaran

2. Isi panduan siswa

3. Petunjuk penggunaan bahan ajar

4. Karakteristik mata pelajaran

5. Karakteristik siswa

6. Ruang lingkup

7. Struktur KI dan KD mapel mulok sejarah daerah bima

8. Strategi pembelajaran dan model umum pembelajaran
9. Penilaian hasil belajar

Adapun komponen panduan siswa sebagai berikut:

1. Identitas mata pelajaran

2. Kompetensi Inti (KI) dan Kompetensi Dasar (KD)

3. Petunjuk penggunaan

4. Kegiatan Belajar

5. Pengayaan

6. Remidal

Pengembangan produk bahan ajar sejarah daerah bima berbantu $Q r$ Codes telah layak digunakan sebagai sumber belajar dalam kegiatan proses pembelajaran untuk menunjang siswa memperoleh ilmu pengetahuan, sehingga nilai-nilai yang terkandung dalam sejarah daerah bima dapat diaplikasikan oleh siswa dalam kehidupan bermasyarakat. Diharapkan produk ini agar dibisa di manfaatkan secepatnya untuk siswa dengan penambahan video-video yang baru sesuai dengan materi pelajaran.

Saran untuk produk yang dihasilkan dapat dimanfaatkan secara maksimal dalam kegiatan pembelajaran, maka terdapat beberapa saran dikembangkan, antara lain:

a. Materi dalam bahan ajar diharapkan mencakup keseluruhan sejarah daerah bima

b. Desain buku agar lebih menarik sesuai dengan karakteristik siswa

c. Bahan ajar yang ada diharapkan dapat dimanfaatkan dengan strategi pembelajaran yang bervariasi

d. Penambahan fitur-fitur teknologi $Q r$ Codes yang terupdate

e. Penambahan video yang sesuai dengan konten

f. Jenis video diharpakan bervariasi seperti animasi stopmotion

DAFTAR RUJUKAN

Arikunto, S., 2008. Dasar-Dasar Evaluasi Pendidikan. Jakarta: Bumi Aksara.

Bachtiar, M., Mazharuddin, A. 2012. Smart Login pada Situs Web Menggunakan Qr-Code. Jurnal Teknik Pomits. Vol. 1, No. 1, Hal. 1-4, (Online), digilib.its.ac.id. Diakses 27 Mei 2017 pukul 11.02 
Degeng, I.N.S. 1997 Strategi Pembelajaran: Mengorganisasikan Isi dengan Model Elaboras. Malang: IKIP Malang.

Dick, W. And Carey, L, dan Carey, J. O. 2009. The Systematic Design of Instructions. New Jersey: Pearson.

Depdiknas. 2006. Pedoman Memilih dan Menyusun Bahan Ajar. Jakarta: Depdiknas

Depdiknas. 2008. Kurikulum Tingkat Satuan Pendidikan. Jakarta: Dikmenum. Depdiknas.

Januszewski, A. \& Molenda. 2008. Educational Technology: A Definition with Commentary. New York: Lawrence Erlbaum Associates: AECT.

Mardiah, A., Suwignyo, H., \& Kuswandi D. 2016. Pengembangan Modul Membaca Intensif Materi Cerita Petualangan Berbasis Saintifik. Vol.1, No.6, Hal. 1115-1119, (Online), http://journal.um.ac.id/index.php/jptpp /article/view. Diakses pada 27 Mei 2017 pukul 11.02 .

Panen, P. \& Purwanto. 2001. Penulis Bahan Ajar. Jakarta: Universitas Terbuka.

Sugiyono. 2011. Metode Penelitian Kuantitatif, Kualitatif, dan $R \& D$. Bandung: Alfabeta.

Taufiqy, I. R.ijal, Sulthoni, \& Kuswandi, D. 2016. Pengembangan Bahan Ajar Digital Berlandaskan Model GuidedProject Based Learning. Jurnal Pendidikan: Teori, Penelitian dan Pengembangan. Vol. 1,No. 4, Hal 705-711, (Online), http://journal.um.ac.id/index.php/jptpp /article/view. Diakses pada 27 Mei 2017 pukul 11.05 . 